\title{
Tension at the top in South African science
}

Cape Town. Shortly after last May's general election in South Africa, President Nelson Mandela established a Ministry of Arts, Culture, Science and Technology, and appointed Dr Ben Ngubane, one of three cabinet members belonging to Mangosothu Buthulezi's Inkatha Freedom Party, as its minister.

At the same time, Mandela chose his estranged wife Winnie, the chairwoman of the African National Congress (ANC)'s Women's League, to be Ngubane's deputy minister. Six months later, the two appear to be going through a tempestuous honeymoon. Whereas Ngubane appears cautious in his desire for change, Mrs Mandela has had little hesitation in expressing her frustration with the inertia of government bureaucracy.

As a result, the two appear sometimes to be out of step. In May, for example, Mrs Mandela announced the establishment of an advisory committee for the ministry; Ngubane announced the establishment of a separate committee in June. It was only after intervention by the deputy-president, Thabo Mbeki, that a 'definitive' committee was finally constituted in August to replace the old Scientific Advisory Council (SAC), whose term of office had lapsed.

The new committee is chaired jointly by Friedel Sellschop, a nuclear physicist and deputy vice-chancellor for research

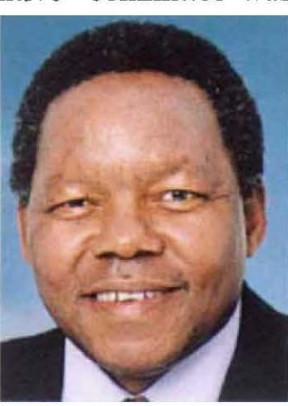

Ngubane: cautious of big changes. at the University of the Witwatersrand, and Fatima Meer, a sociologist at the University of Natal. The minister and his deputy each recommended the appointment of four members to this committee, two for arts and culture, and two for science and technology.

The advisory committee will decide how

that people in the financial industry in New York, London, Washington and Tokyo are all saying the same thing - that climate change threatens the survival of their businesses - and yet no-one has yet responded to it as a risk," says Jeremy Leggett, scientific director of Greenpeace's climate campaign.

Leggett wants insurance companies to switch their investments from fossil fuel businesses, which he says undermine the insurance companies' own market security, to 'greener' programmes such as solar energy and energy-efficient housing. The Delphi report endorses this position, stating that "the alternative energy industry offers greater growth potential than the carbon-fuel industry."

to divide the science vote, currently totalling R886 million (US\$253 million), among the seven research councils (including the newly created Council for Geosciences) and the Bureau of Standards.

The value of the vote has dropped by 27 per cent in real terms since 1987. But Ngubane is confident that it will increase next year, pointing out that, under the terms of the Reconstruction and Development Programme(RDP), the government is committed to now increasing expenditure on research and

\section{IMAGE \\ UNAVAILABLE FOR COPYRIGHT REASONS} development in South Africa.

$\mathrm{He}$ is less optimistic that funds previously allocated to military research will be redirected towards the civil sector, saying that it is "too early" for such a decision. In addition to the science vote, the government provides a R509-million subsidy to the Atomic Energy Corporation and an undisclosed subsidy, which is almost certainly far larger, to the state-owned armaments industry.

Academics have welcomed the appointment of Sellschop and Meer as co-chairs of the advisory committee. Sellschop, in particular, is known to favour a larger portion of the science vote being allocated to agency funding (see Nature 362, 487; 1993).

As before, the advisory committee's recommendations will be forwarded to a cabinet committee, which makes the final allocation of funds. This committee is made up of the ministers of Arts, Culture, Science and Technology, Trade and Industry, Mineral and Energy Affairs, Agriculture, and Health, and is chaired by Ngubane.

ANC ministers are in a minority on this committee. But it may be extended to include the minister responsible for the RDP,

Leggett also wants representatives of the financial sector at the negotiations of the Intergovernmental Panel on Climate Change (IPCC), pointing out that "the oil, coal and auto industries have been represented from day one."

Despite lack of direct representation, Andrew Dlugolecki, from the UK insurance company General Accident, is working with IPCC, which publishes regular scientific assessments of climate change, on a chapter on global warming and the financial sector for a forthcoming report, due in 1995

He says that insurance companies are taking the issue extremely seriously, but that most are reserving judgement. "A change of policy is probably premature", he says, although adding that he believes

\section{the ANC minister Jay Naidoo.}

Ngubane says the most important change is the way in which funds will be allocated to the science councils, increasing the weight given to national needs and priorities in deciding such allocations.

The government's decision has prompted the research councils hurriedly to redraft their existing and planned activities in terms of the new programme's stated aims. Whether funding for basic research will be affected depends heavily on whether the minister is able to persuade the Treasury to increase the value of the science vote.

Ngubane says that he recognizes the role of the Plenary of the Science and Technology Initiative (see Nature 367,$211 ; 1994$ ) as a national forum on science and technology, but feels it should expand its representation. $\mathrm{He}$ has invited the body to commission a foresight study on science and technology within the framework of the RDP.

Ngubane and Mrs Mandela seem to agree on one matter at least: that the RDP should be treated as a holy grail. But they appear to differ in their evaluation of what needs to be done to further its cause. Ngubane is inherently cautious of change. But Mrs Mandela has no such qualms, singling out the Council for Scientific and Industrial Research and the Human Sciences Research Council for criticism in a recent debate on the ministry's budget in parliament. In particular, Mrs Mandela pointed out that the staff of both are "overwhelmingly white and male". She said that this was "not surprising", given that it represented the "direction in which the Nationalists operated their 'affirmative action' policy".

But her harshest criticism was reserved for her own ministry. She claimed that, although the department's staff is trying to accommodate the demands of the RDP, "if truth be told, few have the stomach for it". Ngubane's response to this is that his deputy "was making a political speech, which she is perfectly entitled to do". Michael Cherry

that insurance companies may eventually have to adopt the line suggested by Greenpeace.

Dlugolecki is critical of the lack of interest banks have shown up to now in global warming, despite the fact that many of their long-term investments and loans - such as building projects - are highly vulnerable to natural disasters such as storms, floods and hurricanes.

But banks are beginning to wake up to the dangers. A group of 45 banks from around the world met in Geneva last month for a meeting organized by the United $\mathrm{Na}$ tions on banks and the environment, and British bankers will hold a joint seminar with Greenpeace on the subject next week.

Alison Abbott 